\title{
Early Root Development of Eucalyptus pellita F. Muell. Seedlings from Seed and Stem Cutting Propagation Methods at Nursery Stage
}

\author{
Affendy Hassan $(\mathbb{D}$, Parveena Balachandran $(\mathbb{D}$, and Khairiyyah R. Khamis \\ Forest Plantation and Agroforestry Programme, Faculty of Tropical Forestry, Universiti Malaysia Sabah, Kota Kinabalu 88400, \\ Sabah, Malaysia \\ Correspondence should be addressed to Affendy Hassan; affendy@ums.edu.my
}

Received 14 November 2020; Revised 15 April 2021; Accepted 25 May 2021; Published 9 June 2021

Academic Editor: Qing Lai Dang

Copyright (C) 2021 Affendy Hassan et al. This is an open access article distributed under the Creative Commons Attribution License, which permits unrestricted use, distribution, and reproduction in any medium, provided the original work is properly cited.

\begin{abstract}
Macropropagation using cutting for larger multiplying seedlings is cheaper and efficient instead of clonal seeds for uniform plant material seedling production. However, information on root growth of Eucalyptus pellita at early development from seed and stem cutting of E. pellita seedlings is still lacking. With such information, it is useful for forest plantation company management in enhancing the understanding of strategies to optimize yield production with the appropriate agronomic or silvicultural approach in the field of planting. Therefore, the objectives of this study were to compare the root development of two different types of propagation seedlings of E. pellita and to study the effect of various nitrogen concentration levels on two different types of propagation of E. pellita seedlings. The study was conducted using E. pellita seedlings from two different types of propagation, namely, seed and stem cuttings, along with three different nitrogen concentrations $\left(0,50\right.$, and $\left.200 \mathrm{~kg} \mathrm{~N} \mathrm{ha}^{-1}\right)$. Shoot biomass, root intensity (RI), total root intensity (TRI), root biomass, root length density (RLD), and specific root length (SRL) were recorded. Dried shoot biomass, RLD, and SRL of E. pellita seedlings using stem cutting were significantly higher $(P<0.05)$ compared to seed, whereas there were no significant differences $(P>0.05)$ for root biomass, TRI, and RI between the propagation types of E. pellita seedlings. In conclusion, E. pellita seedlings from stem cutting were greater in terms of root distribution compared to propagation by seeds at the nursery stage, and $50 \mathrm{~kg} \mathrm{~N} \mathrm{ha}^{-1}$ was the optimal nitrogen concentration level from the considered levels to be applied to the E. pellita seedlings.
\end{abstract}

\section{Introduction}

Plantation forestry using Eucalyptus spp. in Sabah, Malaysia, started in the 1970s [1] as part of a forest conservation effort [2]. Eucalyptus is among the important fast-growing species that is typically managed on short rotation to sustain the production of timber, pulpwood, charcoal, and firewood $[2,3]$. Sabah Softwood Berhad (SSB) is the first private forest plantation company in Sabah that pioneered using fastgrowing timber species, where E. deglupta was initially introduced during the early plantation development [4]. However, it was unsuccessful and was later replaced with other superior species such as Acacias, due to poor growth performance [2] and foliar pathogens [5].
For nearly three decades, Acacia mangium and hybrids have been the primary species planted in Sabah, especially in some forest plantation companies such as Acacia Forest Industries Sdn Bhd (AFI), Sabah Forest Development Authority (SAFODA), and SSB. However, A. mangium and hybrids performance are affected mainly by serious fungi Ceratocystis disease [5, 6], wilt [5], and Ganoderma philippii [7], which have caused death to about 10 to $20 \%$ of the Acacia trees in plantations [8]. Therefore, Eucalyptus pellita is an alternative option for the fast-growing timber production industry. Since 2008, most forest plantation companies in Sabah and Sarawak have been involved in using Eucalyptus species in plantations [2]. 
Eucalyptus pellita F. Muell, or red mahogany, is a medium-to-large tree that can grow up to $40 \mathrm{~m}$ in height and over $1 \mathrm{~m}$ in diameter [9]. E. pellita is native to Papua New Guinea and northern Queensland, Australia [10-12]. It has good growth and a high survival rate because of its wider range of adaptability with sites and favourable stem form [13]. Currently, E. pellita plays an important role in reforestation in countries such as Brazil, Cuba, Indonesia, Malaysia, and the Philippines [10]. Furthermore, E. pellita is used for a variety of products such as fine furniture [14], pulp production $[15,16]$, and high-quality writing and printing paper or tissue products [17-19].

In order to sustain the plant material supply with efficient and cost-effective means [20], macropropagation using cutting can be used instead of clonal seeds for uniform plant material seedling production. Cutting is the most widely used technique and is cheaper for larger multiplying seedlings of Eucalyptus, due to easier handling as compared to the micropropagation method [21].

However, although there exist many studies on E. pellita, there is a limited amount of information on root growth of E. pellita at early development from seed and stem cutting of E. pellita seedlings. This is probably due to the difficulty in investigation belowground and also due to methodological problems. With such information, it is useful for forest plantation company management in enhancing the understanding of strategies to optimize yield production with the appropriate agronomic or silvicultural approach. In this present study, we used two different propagation types of planting material sources from seed and stem cutting of E. pellita and studied their root traits at three different nitrogen concentrations. On this basis, the objectives of this study were formulated as follows: (i) to compare the root development of two different types of propagation seedlings of E. pellita and (ii) to study the effect of different nitrogen concentrations on two different types of propagation of E. pellita seedlings. We hypothesized that, both above and belowground, E. pellita seedlings from stem cutting were greater than seedlings from seed propagation.

\section{Materials and Methods}

2.1. Experiment Description. This study was conducted from the $12^{\text {th }}$ of April to the $30^{\text {th }}$ of August 2019 at a greenhouse at the Faculty of Tropical Forestry, Universiti Malaysia Sabah (UMS), Kota Kinabalu, Sabah, Malaysia $\left(6^{\circ} 02^{\prime} 08.4^{\prime \prime} \mathrm{N} 116^{\circ} 07^{\prime} 34.4^{\prime \prime} \mathrm{E}\right)$. According to the Malaysia Meteorological Department 2020 (http://www.met.gov.my), the temperature was in the range of 30 to $32^{\circ} \mathrm{C}$, while rainfall distribution was in the range of $111.76 \mathrm{~mm}$ (April) to $304.80 \mathrm{~mm}$ (June), throughout the study period. A transparent plastic pot $20 \mathrm{~cm}$ in height $\times 140 \mathrm{~mm}$ in inner diameter, which had a total volume of $3,079 \mathrm{~cm}^{3}$, was used as the medium pot. The bottom of the container was created with small holes to facilitate the flow of water and air and was covered with a fine net. Each pot had four sides for grid lines, which were marked as sides $\mathrm{A}, \mathrm{B}, \mathrm{C}$, and $\mathrm{D}$ using a red permanent marker. The grid size was $20 \times 20 \mathrm{~mm}$, and the total grid length for each side was $1.42 \mathrm{~m}$ (Figure 1). This involved repeatedly counting the number of intersections of the roots along the grid lines. During the experiment, the pot was always covered using nontransparent plastic to avoid light exposure of the soil and roots and was opened only during the measurement process. Topsoil was taken from Tamparuli district, Sabah (30 km from the UMS campus). The soil properties were light grey (10YR 7/1) to grey (10YR 6/1, 5YR 6/1) to light brownish grey $(2.5 \mathrm{Y} 6 / 2)$ with or without common yellowish brown (10YR 5/6) or red (10R 4/8) mottles; loamy sand to clay; $\mathrm{pH}$ 4.5-5.8; and cation exchangeable capacity (CEC) very friable between 2 and $20 \mathrm{cmol}_{+} \mathrm{kg}^{-1}$ [22]. The soil was airdried for seven days in a greenhouse, sieved using a $2.0 \mathrm{~mm}$ soil mesh, and filled into a pot. The moisture content of the soil sample before the experiment was $15.8 \%$. After that, the soil in the pot was washed with $5 \mathrm{~L}$ of water under low water pressure, to ensure all the nutrients in the soil were empty or low and homogenized.

In this experiment, seedlings of four-week-old E. pellita propagated from seeds, and stem cutting was supplied from Acacia Forest Industries Sdn. Bhd. (AFI). Stem cutting was produced from their superior mother clonal plants. The tip was selected for cutting; the rooting duration was four weeks in a greenhouse, prior to the experiment. The seedlings were then transferred to the pot that was filled with the topsoil. The 36 E. pellita seedlings from seeds and 36 E. pellita seedlings from stem cutting, accounting for a total of 72 experimental units, including three replications (12 replicates for each fertilizer treatment), were arranged using a complete randomized design (CRD). A liquid nitrogen fertilizer (AG Leader 954) was diluted and corresponded to the three different rates of 0 (control), $50 \mathrm{~N} \mathrm{~kg} \mathrm{ha}^{-1}(0.16 \mathrm{ml}$ of $\mathrm{N} \mathrm{pot}^{-1}$, which is $153.9 \mathrm{~m}^{2}$ of soil surface of each pot), and $200 \mathrm{~N} \mathrm{~kg} \mathrm{ha}^{-1}\left(0.62 \mathrm{ml}\right.$ of $\left.\mathrm{N}_{\text {pot }}{ }^{-1}\right)$. No watering was done as the experiment was exposed to natural conditions.

2.2. Data Collection. In this experiment, dried shoot biomass, root biomass, root intensity (RI), total root intensity (TRI), root length density (RLD), and specific root length (SRL) were recorded [23]. RI data was collected based on the method by Thorup-Kristensen [24]. RI was measured by counting the number of roots crossing the lines of $20 \times 20 \mathrm{~mm}$ grid squares placed on the container surface view sides (Figure 1). RI data was recorded every week, starting from when the roots started to appear on the surface of the transparent pot until the roots reach the bottom of the pot.

Three different sampling dates were carried out 4, 6, and 8 weeks after transplanting (WAT). Figure 2 presents the samples of E. pellita from both seed and stem cutting at second harvest at different fertilizer treatments. Each sampling involved the harvesting of 12 experimental units, or four (4) replicates for each fertilizer treatment from both planting materials. Aboveground biomass was cut from the ground topsoil, washed, and placed in a labelled heat resistant plastic bag. It was then kept in an oven at $70^{\circ} \mathrm{C}$ for 48 hours, before being weighed. For root parameters, roots biomass was washed out from the soil and organic matter using a sieve $2.0 \mathrm{~mm}$ mesh under low-pressure water. It was 


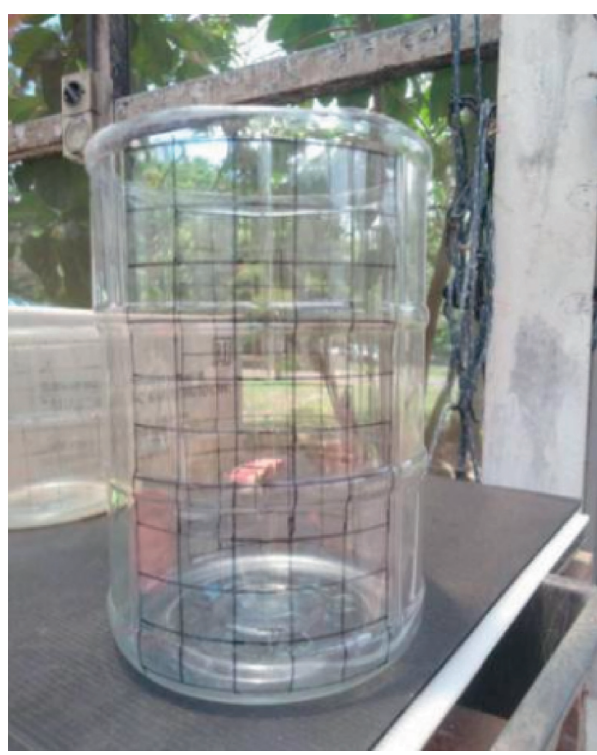

(a)

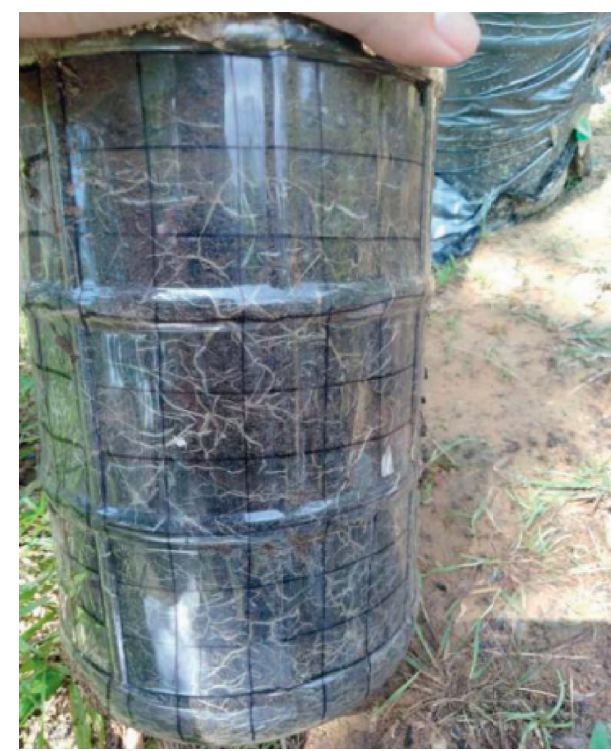

(b)

FIGURE 1: Drawing gridline at external pot (grid size $20 \times 20 \mathrm{~mm}$ ) before the experiment (a) and root counting for root intensity (RI) (b).

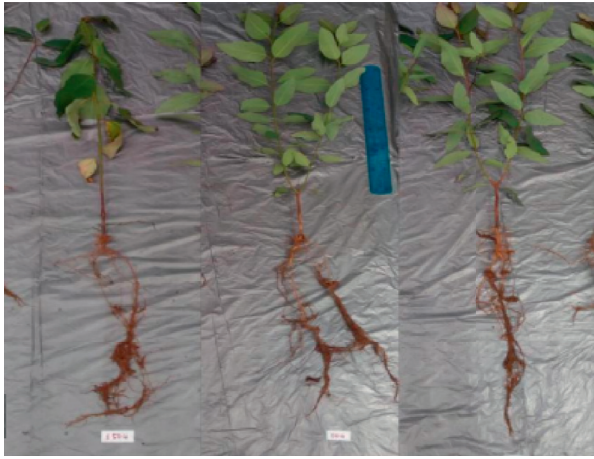

(a)

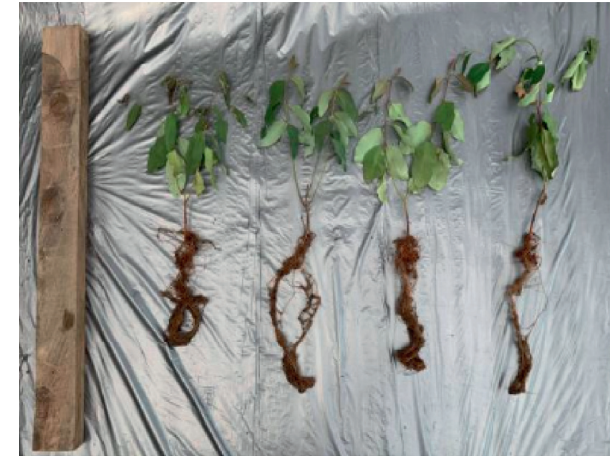

(b)

FIgURE 2: Above- and belowground samples of E. pellita seedlings (a) and stem cutting (b) at second harvest.

then stored in $50 \%$ ethanol in a $50 \mathrm{ml}$ Eppendorf tube at $5^{\circ} \mathrm{C}$, before root image analysis. RLD $\left(\mathrm{cm} \mathrm{cm}^{-3}\right)$ was determined using an EPSON ${ }^{\circledR}$ scanner and Winrhizo ${ }^{\circledR}$ software and expressed in $\mathrm{cm} \mathrm{cm}^{-3}$ [23] (Figure 3). After RLD measurement, SRL $\left(\mathrm{cm} \mathrm{g}^{-1}\right)$ was measured afterwards, whereby the length of a subsample was measured, and then divided by its mass ( $\mathrm{g}$ ), before being converted to actual root biomass.

2.3. Statistical Analysis. All the mean values were subject to statistical analysis using the Statistical Package Social Science (IBM SPSS Statistics 22.0). An independent sampled $t$-test was used to compare the TRI, RLD, SRL, root biomass, and shoot biomass between two types of plant material E. pellita seedlings at various nitrogen concentrations for all sampling dates. Subsequently, a one-way ANOVA followed by Tukey HSD's post hoc analysis was used for RI at different nitrogen concentrations for both seed and stem cutting seedlings. In assessing the differences between the results, tests with
$P<0.05$ were considered statistically significant. Prior to statistical analyses, all data were tested for normality using the Shapiro-Wilk Normality test and for homogeneity using Levene's test.

\section{Results}

3.1. Dried Shoot Biomass for E. pellita. Dried shoot biomass was harvested three times, four, six, and eight weeks after transplanting $(4,6,8 \mathrm{WAT})$, as indicated in Figure 4. It is clear that there was a significant difference $(P<0.05)$ of dried shoot biomass of E. pellita seedlings between seedling and stem cutting, especially at 6 WAT. At 4 WAT, there was no significant difference between seed and stem cutting for both 0 and $50 \mathrm{~kg} \mathrm{Nha}^{-1}$, but the shoot biomass of stem cutting was nearly double the seed under $200 \mathrm{~kg} \mathrm{~N} \mathrm{ha}^{-1}$. In contrast, at $6 \mathrm{WAT}$, all the treatments showed a significant difference $(P<0.05)$, where $50 \%$ of stem cutting was higher 


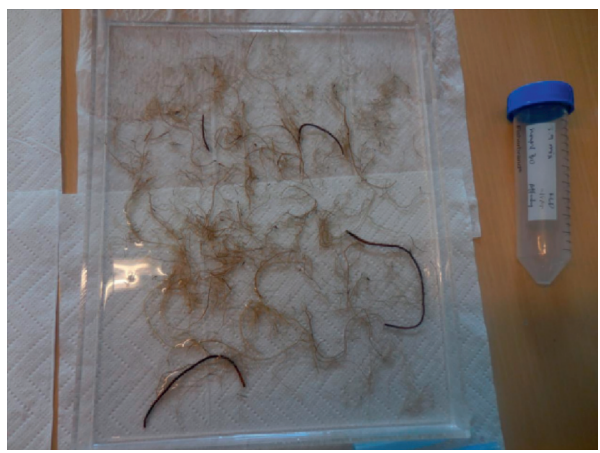

(a)

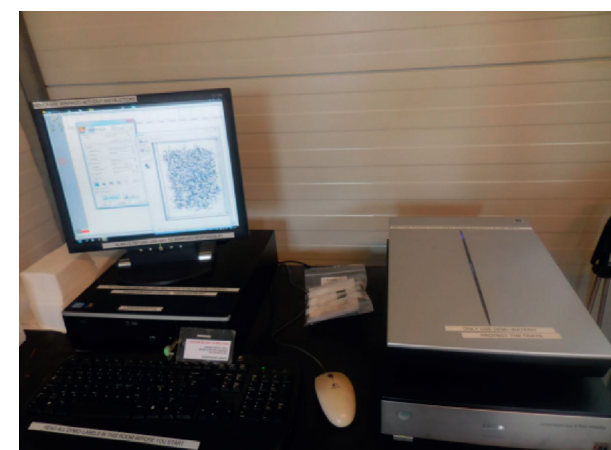

(b)

FIGURE 3: Root sample is placed in the root tray (a), for RLD determination using an EPSON ${ }^{\circledR}$ scanner and Winrhizo ${ }^{\circledR}$ software (b).

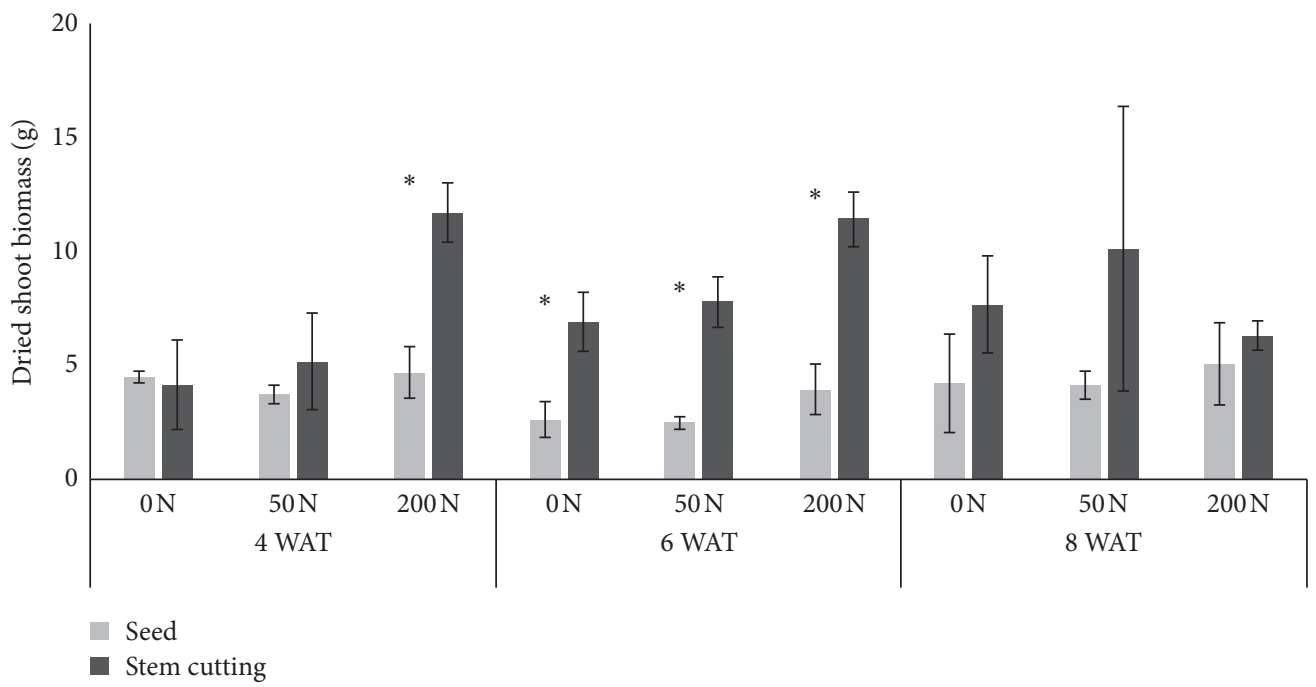

Figure 4: Dried shoot biomass ( $\mathrm{g}$ ) of E. pellita seedlings from seeds and stem cutting plant materials at different nitrogen concentrations ( 0 , $50,200 \mathrm{~kg} \mathrm{~N} \mathrm{ha}^{-1}$ ) at three selected dates of root measurement: 4 weeks after transplanting, WAT, 6 WAT, and 8 WAT. The mean values were tested using independent samples $t$-test between seed and stem cutting propagation for each fertilizer treatment and date. All mean values were significantly different ${ }^{*}(P<0.05)$. Error bars denote standard deviations of the mean $(n=4)$.

than seed. However, there was no significant difference between seed and stem cutting for all treatments at 8 WAT.

3.2. Root Biomass of E. pellita. There was no significant difference $(P>0.05)$ between the seedling and stem cutting of E. pellita for all treatments in 4 WAT (Figure 5). However, in $6 \mathrm{WAT}$, only for $50 \mathrm{~kg} \mathrm{Nha}^{-1}$, the seed propagation of E. pellita showed a significant difference $(P<0.05)$, as compared to stem cutting. Interestingly, without fertilizer, the root biomass of E. pellita seeds was significantly higher $(P<0.05)$, as compared to stem cutting.

3.3. Total Root Intensity of E. pellita from Seed and Stem Cutting. In comparison, the total root intensity (TRI) of E. pellita stem cutting was significantly higher $(P<0.05)$ compared to seed propagation for all measurement dates (Figure 6). Despite the large variations observed in stem cutting treatment, the TRI remained to be nearly double that of seed cutting, especially at 6 and 8 WAT.

3.4. Root Intensity of E. pellita at Different Nitrogen Concentrations. Figure 7 shows a comparison of root intensity (RI) of E. pellita from seed propagation (Figure 7(a)) and stem cutting (Figure 7(b)), at various measurement dates and nitrogen concentrations. According to the findings, there was no significant difference $(P>0.05)$ for treatments and types of plant material for each measurement date. However, despite the large variations of RI, E. pellita stem cutting was clearly higher and increased with the measurement dates, as compared to seed propagation (Figure 7(b)).

3.5. Root Length Density of E. pellita. Figure 8 shows the root length density (RLD) of E. pellita, both from seed and stem cutting, taken at three independent harvest times. Based on 


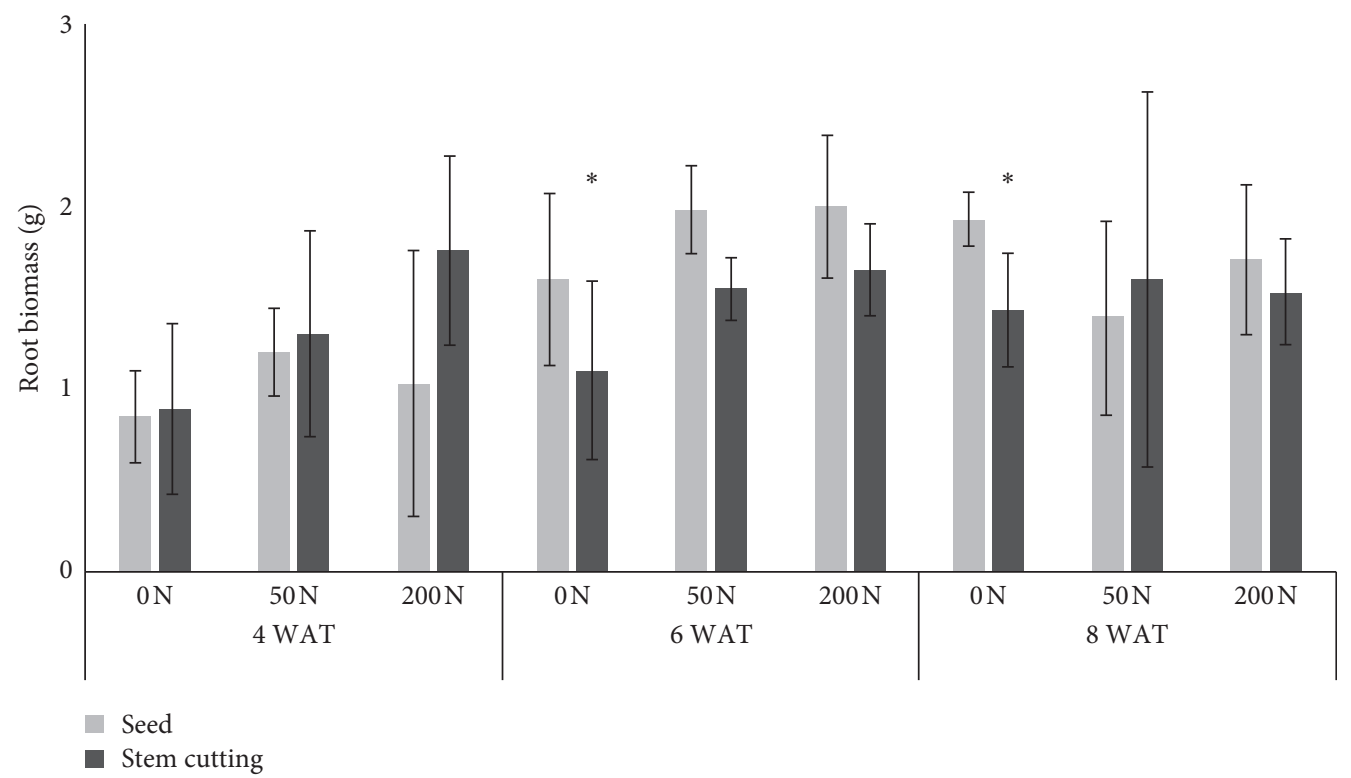

Figure 5: Root biomass (g) of E. pellita seedlings from seeds and stem cutting plant materials at different nitrogen concentrations $(0,50$, and $200 \mathrm{~kg} \mathrm{~N} \mathrm{ha}^{-1}$ ) at three selected dates of root measurement: 4 weeks after transplanting, WAT, 6 WAT, and 8 WAT. The mean values were tested using independent samples $t$-test between seed and stem cutting propagation for each fertilizer treatment and date. All mean values were significantly different ${ }^{*}(P<0.05)$. Error bars denote standard deviations of the mean $(n=4)$.

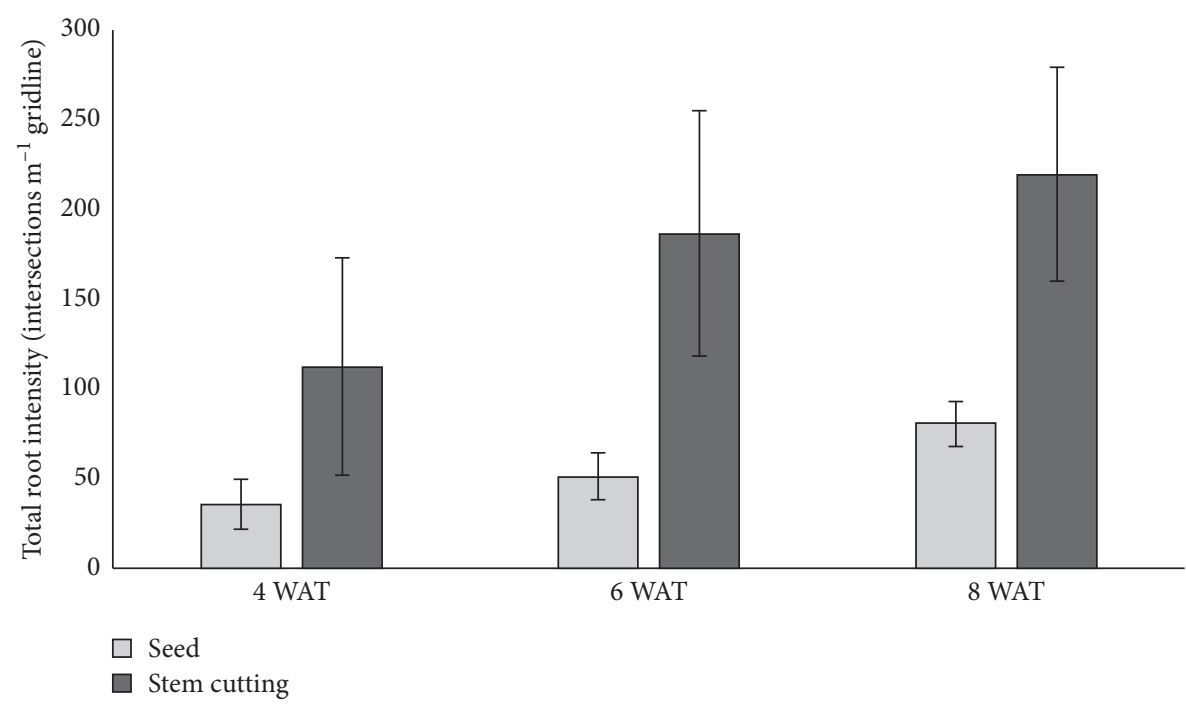

Figure 6: Total root intensity (intersections $\mathrm{m}^{-1}$ gridline) of E. pellita seedlings from seeds and stem cutting plant materials at three selected dates of root measurement $(4,6$, and 8 weeks after transplanting, WAT). The mean values tested using independent samples $t$-test and statistically the mean values were different $(P<0.05)$. Bars represent standard deviations of the mean, $n=36(4 \mathrm{WAT})$, $n=24(6 \mathrm{WAT})$, and $n=12$ (8 WAT).

the results, stem cutting of E. pellita was significantly higher at $200 \mathrm{~kg} \mathrm{Nha}^{-1}$ than at the control and at $50 \mathrm{~kg} \mathrm{Nha}^{-1}$. At 6 WAT, all RLDs of stem cutting of E. pellita were significantly higher $(P<0.05)$ compared to seed propagation, for all $\mathrm{N}$ concentrations. However, the RLD of stem cutting of E. pellita was significantly higher compared to seedling under the control and high $\mathrm{N}$ concentrations, on the final measurement date. It was also found that the RLD of E. pellita for both seed and stem cutting under fertilizer treatment decreased with the measurement dates.
3.6. Specific Root Length (SRL) of E. pellita. The specific root length (SRL) of E. pellita was significantly higher $(P<0.05)$ for all treatments and measurement dates (Figure 9). At 4 WAT, SRL of stem cutting was significantly higher $(P<0.05)$ compared to seed propagation, almost threefold, especially at high $\mathrm{N}$ concentrations. Similar findings were also found at 6 WAT, which was almost $50 \%$ higher $(P<0.05)$ than seed propagation for all fertilizer treatments. However, at 8 WAT, SRL was found to be significantly higher for approximately $50 \%$ of stem cutting, as compared to seed 


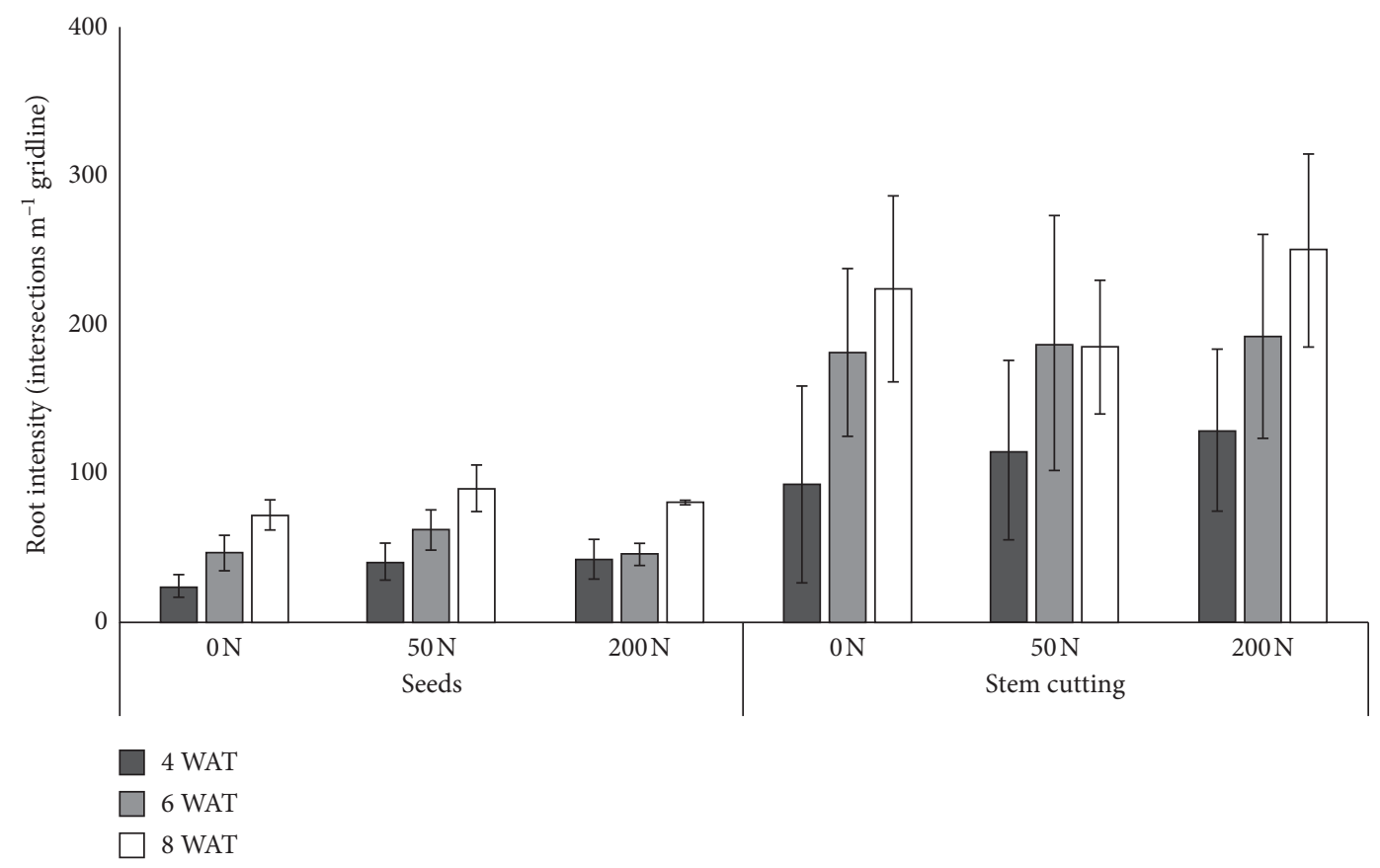

Figure 7: Root intensity (intersections $\mathrm{m}^{-1}$ gridline) of E. pellita seedlings from seeds and stem cutting at different $\mathrm{N}$ concentrations $\left(0,50\right.$, and $\left.200 \mathrm{~kg} \mathrm{~N} \mathrm{ha}^{-1}\right)$ at three selected dates of root measurement $(4,6$, and 8 weeks after transplanting, WAT). The mean values were tested using ANOVA followed by Tukey HSD's post hoc Test. The mean values were not significantly different between the different $\mathrm{N}$ concentrations for each date $(P>0.05)$. Bars represent standard deviations of the mean, $n=12(4 \mathrm{WAT}), n=8(6 \mathrm{WAT})$, and $n=4$ ( 8 WAT).

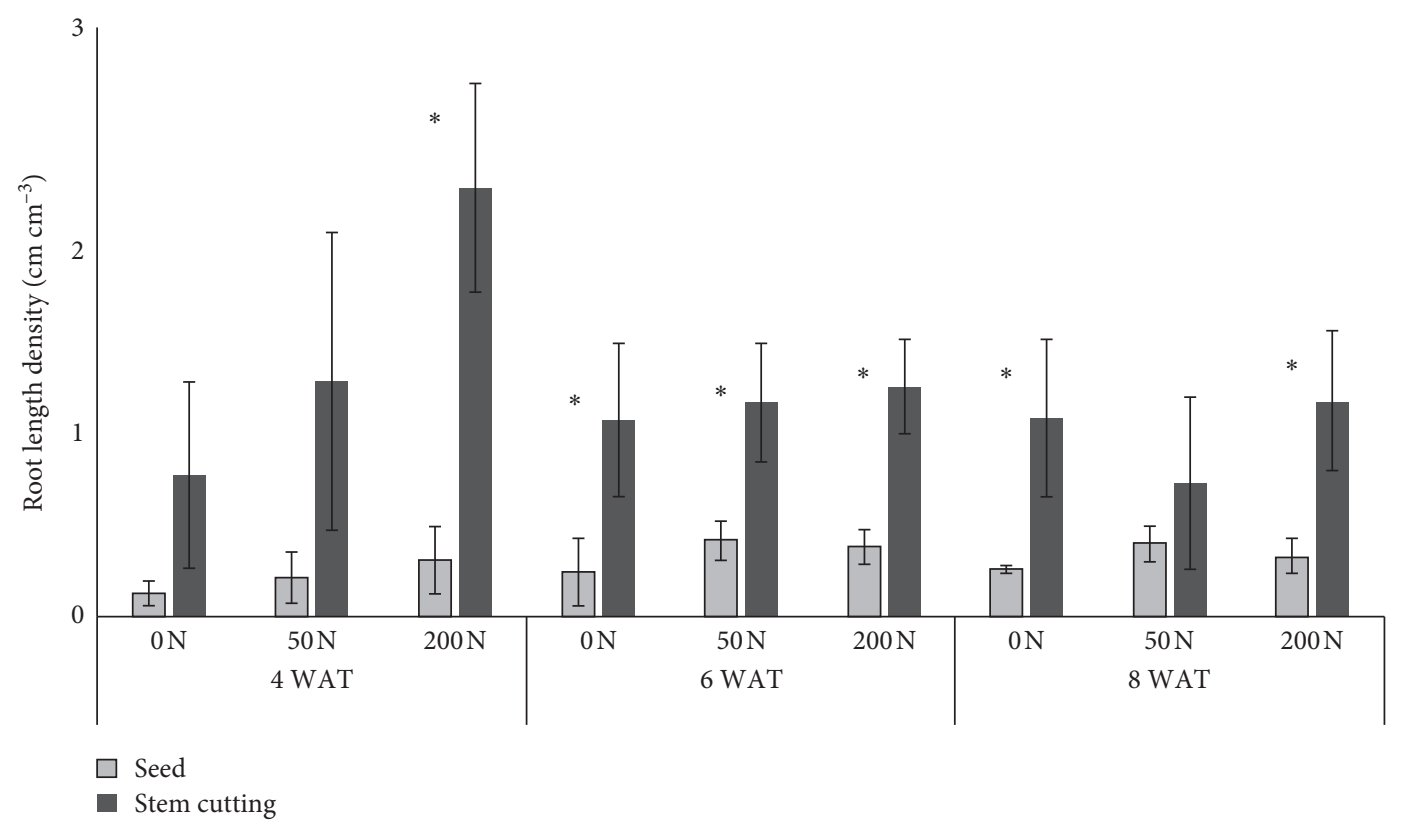

Figure 8: Root length density $\left(\mathrm{cm} \mathrm{cm}^{-3}\right)$ of E. pellita seedlings from seeds and stem cutting plant material at different nitrogen concentrations $\left(0,50\right.$, and $\left.200 \mathrm{~kg} \mathrm{~N} \mathrm{ha}^{-1}\right)$ at three selected dates of root measurement" 4 weeks after transplanting, WAT, $6 \mathrm{WAT}$, and $8 \mathrm{WAT}$. The mean values were tested using independent samples $t$-test between seed and stem cutting propagation for each fertilizer treatment and date. All mean values were significantly different ${ }^{*}(P<0.05)$. Error bars denote standard deviations of the mean $(n=4)$. 


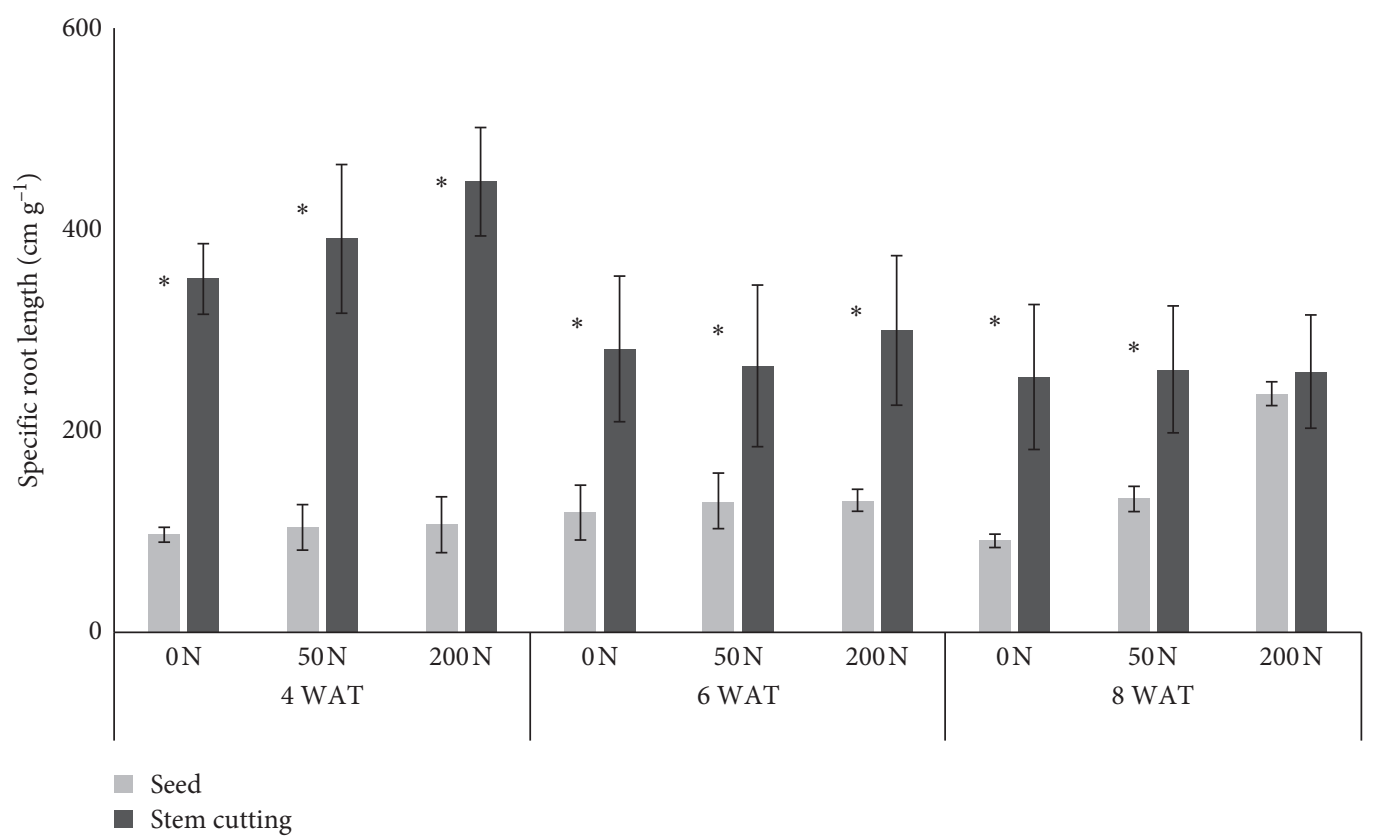

FIGURE 9: Specific root length $\left(\mathrm{cm} \mathrm{g}^{-1}\right)$ of E. pellita seedlings from seeds and stem cutting plant materials at different nitrogen concentrations $\left(0,50\right.$, and $\left.200 \mathrm{~kg} \mathrm{~N} \mathrm{ha}^{-1}\right)$ at three selected dates of root measurement: 4 weeks after transplanting, WAT, 6 WAT, and 8 WAT. The mean values were tested using independent samples $t$-test between seed and stem cutting propagation for each fertilizer treatment and date. All mean values were significantly different ${ }^{*}(P<0.05)$. Error bars denote standard deviations of the mean $(n=4)$.

propagation, at zero and $50 \mathrm{~kg} \mathrm{Nha}^{-1}$. No difference in SRL was found between stem cutting and the seed of E. pellita at $200 \mathrm{~kg} \mathrm{Nha}^{-1}$.

\section{Discussion}

The findings demonstrate that the shoot biomass of stem cutting of E. pellita seedlings was greater compared to seedlings from seed propagation. The shoot biomass is connected with root distribution in the soil, especially the fine roots from stem cutting. The larger the fine root density, the more water and nutrients are taken up, expressed by higher shoot biomass. This is confirmed by Rostamza et al. [25], who reported that greater root length in millet is connected to an increased shoot biomass. Besides that, biomass is also influenced by species and specific silviculture such as irrigation [26], fertilization, and water availability [27].

In root biomass, most of the mean values did not differ for seed and stem cutting. However, Coleman et al. [28] reported that root biomass tends to increase with fertilizer rate, but the proportion of root biomass tends to decrease with more fertilizer application. This argument is associated with the current findings, especially for higher nitrogen concentrations, showing that there is no increase in fertilization rate. Another explanation of the results is that seedlings from seed were higher compared to stem cutting and had no significant difference because seed produces tap root and high root mass, while stem cutting produces fibrous and fine roots.

The distribution of RI was higher in stem cutting compared to seed, although there was no significant difference. This shows that there are more fine roots in stem cutting than in seed propagation, which increased with the measurement date (Figure 7). The findings of this study are in agreement with prior work that has proven that more root distribution, especially for fine roots, is closely associated with soil water and nutrients [29-31]. This explains the presence of more fine roots under stem cutting on the soil.

Despite stem cutting being higher compared to seedling, especially in shoot biomass, in SRL and RLD, these growth parameters were not affected by different nitrogen levels. Especially at high nitrogen concentrations (Figure 9), the SRL did not differ between the propagation types. Previous work reported various responses of fertilizer rates against Eucalyptus in Brazil [32-34], in Australia [35, 36], and in South Africa [37]. Nevertheless, fertilizer responses varied, depending on the species and sites considered [38]. Eucalyptus in Brazil and South Africa responded to fertilization when water was available $[34,37]$. Stape et al. [33] reported that the application of very high rates and excessive nitrogen levels in Brazil did not show any significant effects on Eucalyptus productivity [38]. Fertilizer rates from 50 to $100 \mathrm{~kg} \mathrm{Nha}^{-1}$ increased biomass, but then biomass decreased at a rate of $200 \mathrm{~kg} \mathrm{Nha}^{-1}$ [38]; this was also reported in the present study. Graciano et al. [39] reported that $\mathrm{P}$ applications affected $E$. grandis biomass more than $\mathrm{N}$ applications in Argentina. However, we cannot validate this argument, since this present study did not test E. pellita seedlings using $\mathrm{P}$ fertilizer.

In this case, $50 \mathrm{~kg} \mathrm{Nha}^{-1}$ could be more efficient to absorb by E. pellita, as opposed to $200 \mathrm{~kg} \mathrm{~N} \mathrm{ha}^{-1}$. Chen et al. [40] reported that moderate nitrogen fertilizer increased the 
root intensity in soil layers. As explained above, the root distribution from seedling is less compared to stem cutting or clonal seedling.

In the comparison between seedling and stem cutting, as the above findings, propagation by stem cutting of E. pellita was proved to be viable and productive in terms of root performance at the nursery stage. Although there are works in the related literature that have proved that seed propagation is still the better propagation method [41], producing plant material using stem cutting is relatively more efficient and faster, able to reduce the production costs and time spent for upkeep and maintenance in the nursery. But, it also depends on the species, objectives, and size of the nursery. Partelli et al. [42] also supported the fact that the cutting-propagated method for coffee is more productive than the seed-propagated method. Furthermore, Naidu and Jones [43] also suggested a superior initial survival and growth of $E$. dunnii mini cuttings compared to seedlings based on early indications. This finding has also proven that secondary branches as semihard wood cuttings could be the most effective propagation material of Jatropha curcas [44].

Notwithstanding this, the rooting ability of cuttings from woody or perennial plants declined with an increase in the age of the mother plants [44]. Root ability of cutting formation becomes more difficult with a farther position from the apical shoot [45], due to differences in the type and number of carbohydrates and other stored materials [45, 46]. Therefore, root system characteristics are known to differ according to species, genotype, plant age, physiological status of mother plant [47], season, climate, plant density, root diameter, biotic stresses, and soil texture and structure [48]. Also, the growth rate of stem cutting depends on age variation, position in stem, and diameter of stem [49].

The present study, therefore, provides more information and understanding on E. pellita for forest plantation companies in producing plant materials using stem cutting in a cost-effective and optimal fertilizer consumption. Further research is required on the root aspect, especially in real field conditions, as the soil is more heterogenous and exhibits different environmental conditions. Such findings will help forest plantation companies take agronomic measures and a silvicultural approach.

\section{Conclusion}

To conclude, E. pellita seedlings from stem cutting were greater in terms of root distribution compared to propagation by seedlings, at the nursery stage. In addition, the aboveground biomass of stem cutting was also higher in E. pellita seedlings than that of seed propagation. The $50 \mathrm{~kg} \mathrm{~N} \mathrm{ha}^{-1}$ was the optimal nitrogen concentration to be applied to the E. pellita seedlings.

\section{Data Availability}

The data that support the findings of this study are available from the corresponding author, upon reasonable request.

\section{Disclosure}

The presentation of the earlier version of the manuscript is in preprint in the research square.

\section{Conflicts of Interest}

The authors declare that there are no conflicts of interest regarding the publication of this paper.

\section{Acknowledgments}

The authors acknowledge the staff of Acacia Forest Industries Sdn Bhd (AFI) and technical staff of Faculty of Tropical Forestry, UMS, during the study in technical support. The authors thank Acacia Forest Industries Sdn Bhd (AFI) for its kind support during the study, especially in sponsoring the seedlings and technical support.

\section{References}

[1] C. E. Harwood and S. Nambiar, "Sustainable plantation forestry in South-East Asia," ACIAR Techical Report 84, CSIRO, Canberra, Australia, 2014.

[2] S. Zaiton, M. R. Sheriza, R. Ainishifaa, K. Alfred, and K. Norfaryanti, "Eucalyptus in Malaysia: review on environmental impacts," Journal of Landscape Ecology, vol. 13, no. 2, pp. 79-94, 2020.

[3] X. Zhou, H. Zhu, Y. Wen et al., "Effects of understory management on trade-offs and synergies between biomass carbon stock, plant diversity and timber production in eucalyptus plantations," Forest Ecology and Management, vol. 410, pp. 164-173, 2018.

[4] T. Enters, P. B. Durst, and C. Brown, "What does it take? The role of incentives in forest plantation development in the asiapacific region," 2002, http://www.fao.org/forestry/5247021bfef4098d1413fbbcd9a64c8103fbd.pdf.

[5] Y. Japarudin, M. Lapammu, A. Alwi, D. Boden, and M. J. Wingfield, "Optimising the performance of Eucalyptus pellita in the wet tropics of borneo," in Proceedings of the IUFRO Eucalypt Conference 2015, Zhanjiang, Guangdong, China, October 2015.

[6] M. Tarigan, J. Roux, M. Van Wyk, B. Tjahjono, and M. J. Wingfield, "A new wilt and die-back disease of Acacia mangium associated with Ceratocystis manginecans and C. acaciivora sp. nov. in Indonesia," South African Journal of Botany, vol. 77, no. 2, pp. 292-304, 2011.

[7] C. L. Mohammed, A. Rimbawanto, and D. E. Page, "Management of basidiomycete root- and stem-rot diseases in oil palm, rubber and tropical hardwood plantation crops," Forest Pathology, vol. 44, no. 6, pp. 428-446, 2014.

[8] S. K. Wong, Y. Ahmad Zuhaidi, G. D. C. Charles et al., "Recommending Eucalyptus species for soft loan financing," in Proceedings of the Working Paper Presented at the 1st Technical Meeting On Forest Plantation Programme, Malaysian Timber Industry Board (MTIB), Kuala Lumpur. Malaysia, January 2015.

[9] C. E. Harwood, Eucalyptus Pellita: An Annotated Bibliography, CSIRO, Canberra, Australia, 1998.

[10] T. D. Hung, J. T. Brawner, R. Meder et al., "Estimates of genetic parameters for growth and wood properties in $\mathrm{Eu}$ calyptus pellita F. Muell. to support tree breeding in Vietnam," Annals of Forest Science, vol. 72, no. 2, pp. 205-217, 2015.

[11] A. Yahya, N. Hasnida, L. N. Tong, H. L. Hong, and Z. Fauzeyana Ain, "Comparing the early growth performance of plantation-grown Eucalyptus hybrid and Eucalyptus pellita, South Johore, Peninsular Malaysia," World Journal of Advanced Research and Reviews, vol. 6, no. 2, pp. 234-238, 2020. 
[12] S. Y. Hii, K. S. Ha, M. L. Ngui et al., “Assessment of plantationgrown Eucalyptus pellita in borneo, Malaysia for solid wood utilisation," Australian Forestry, vol. 80, no. 1, pp. 1-8, 2015.

[13] A. Z. Yahya, "Planting of Eucalyptus in Malaysia," Acta Scientific Agriculture, vol. 4, no. 2, pp. 139-140, 2020.

[14] B. Clarke, I. McLeod, and T. Vercoe, Trees for Farm Forestry: 22 Promising Species, CSIRO, Canberra, Australia, 2009.

[15] K. Eldridge, J. Davidson, C. Harwood et al., Eucalypt Domestication and Breeding, Clarendon, Oxford, UK, 1993.

[16] F. S. Poke and C. A. Raymond, "Predicting extractives, lignin, and cellulose contents using near infrared spectroscopy on solid wood in Eucalyptus globulus," Journal of Wood Chemistry and Technology, vol. 26, no. 2, pp. 187-199, 2006.

[17] C. A. Raymond, "Genetics of Eucalyptus wood properties," Annals of Forest Science, vol. 59, no. 5-6, pp. 525-531, 2002.

[18] C. A. Raymond and L. R. Schimleck, "Development of near infrared reflectance analysis calibrations for estimating genetic parameters for cellulose content in Eucalyptus globulus," Canadian Journal of Forest Research, vol. 32, no. 1, pp. 170176, 2002.

[19] L. R. Schimleck, P. D. Kube, C. A. Raymond, A. J. Michell, and J. French, "Extending near infrared reflectance (NIR) pulp yield calibrations to Newsites and species," Journal of Wood Chemistry and Technology, vol. 26, no. 4, pp. 299-311, 2006.

[20] S. Kuppusamy, S. Ramanathan, S. Sengodagounder et al., "Minicutting-a powerful tool for the clonal propagation of the selected species of the Eucalyptus hybrid clones based on their pulpwood studies," Biocatalysis and Agricultural Biotechnology, vol. 22, pp. 1-4, 2019.

[21] E. D. Sulichantini, M. Sutisna, Sukartiningsih et al., "Clonal propagation of two clones Eucalyptus pellita F. Muell by minicutting," The International Journal of Engineering Science, vol. 6, no. 2, pp. 112-116, 2014.

[22] E. Malangkig, R. Mahali, and J. Ongkosing, "Soil monograph of Sabah," Department of Agriculture Sabah, vol. 62, 2009.

[23] A. Hassan, D. B. Dresbøll, C. R. Rasmussen et al., "Root distribution in intercropping systems-a comparison of DNA based methods and visual distinction of roots," Archives of Agronomy and Soil Science, vol. 67, no. 1, pp. 15-28, 2021.

[24] K. Thorup-Kristensen, "Are differences in root growth of nitrogen catch crops important for their ability to reduce soil nitrate-N content, and how can this be measured?" Plant and Soil, vol. 230, no. 2, pp. 185-195, 2001.

[25] M. Rostamza, R. A. Richards, and M. Watt, "Response of millet and sorghum to a varying water supply around the primary and nodal roots," Annals of Botany, vol. 112, no. 2, pp. 439-446, 2013.

[26] O. P. Toky, D. Riddle-Black, P. J. C. Harris et al., "Biomass production in short rotation effluent-irrigated plantations in North-West India," Journal of Scientific and Industrial Research, vol. 70, pp. 601-609, 2011.

[27] A. Ares, D. M. Burner, and D. K. Brauer, "Soil phosphorus and water effects on growth, nutrient and carbohydrate concentrations, $\delta 13 \mathrm{C}$, and nodulation of mimosa (Albizia julibrissin Durz.) on a highly weathered soil," Agroforestry Systems, vol. 76, no. 2, pp. 317-325, 2009.

[28] M. D. Coleman, A. L. Friend, and C. C. Kern, "Carbon allocation and nitrogen acquisition in a developing Populus deltoidesplantation," Tree Physiology, vol. 24, no. 12, pp. 1347-1357, 2004.
[29] D. Zhang, X. Jiang, and S. Zhao, "Further thoughts on growth redundancy," Acta Prataculturae Sinica, vol. 4, no. 3, pp. 17-22, 1995.

[30] J. Wang, "The root system development of Cicer milkvetchinthe first year of growth," Pratacult Science, vol. 7, no. 1, pp. 53-60, 1990.

[31] M. Zhao, C. Tan, and D. He, "A study of root system of Artemisia dalailamen," Pratacult Science, vol. 7, no. 3, pp. 55-57, 1990.

[32] J. L. d. M. Gonçalves, J. L. Stape, J.-P. Laclau, P. Smethurst, and J. L. Gava, "Silvicultural effects on the productivity and wood quality of eucalypt plantations," Forest Ecology and Management, vol. 193, no. 1-2, pp. 45-61, 2004.

[33] J. Gonçalves, J. Stape, J.-P. Laclau, J.-P. Bouillet, and J. Ranger, "Assessing the effects of early silvicultural management on long-term site productivity of fast-growing eucalypt plantations: the Brazilian experience," Southern Forests: A Journal of Forest Science, vol. 70, no. 2, pp. 105-118, 2008.

[34] J. L. Stape, D. Binkley, M. G. Ryan et al., "The Brazil Eucalyptus potential productivity project: influence of water, nutrients and stand uniformity on wood production," Forest Ecology and Management, vol. 259, no. 9, pp. 1684-1694, 2010.

[35] P. Smethurst, G. Holz, M. Moroni, and C. Baillie, "Nitrogen management in Eucalyptus nitens plantations," Forest Ecology and Management, vol. 193, no. 1-2, pp. 63-80, 2004.

[36] D. S. Mendham, T. S. Grove, A. M. O'Connell et al., Impacts of Inter-Rotation Site Management On Soil Nutrients And Plantation Productivity in Eucalyptus globulus Plantations in South-Western Australia, Center for International Forestry Research, Bogor, Indonesia, 2008.

[37] B. Du Toit, C. W. Smith, K. M. Little, G. Boreham, and R. N. Pallett, "Intensive, site-specific silviculture: manipulating resource availability at establishment for improved stand productivity. A review of South African research," Forest Ecology and Management, vol. 259, no. 9, pp. 1836$1845,2010$.

[38] S. S. T. Halomoan, Wawan, and Adiwirman, "Effect of fertilization on the growth and biomass of Acacia mangium and Eucalyptus hybrid (E. grandis $\times$ E. Pellita)," Journal of Tropical Soils, vol. 20, no. 3, pp. 157-166, 2015.

[39] C. Graciano, J. F. Goya, J. L. Frangi, and J. J. Guiamet, "Fertilization with phosphorus increases soil nitrogen absorption in young plants of Eucalyptus grandis," Forest Ecology and Management, vol. 236, no. 2-3, pp. 202-210, 2006.

[40] S. Chen, R. Arnold, Z. Li et al., "Tree and stand growth for clonal E. urophylla $\times$ grandis across a range of initial stockings in southern China," New Forests, vol. 41, no. 1, pp. 95-112, 2011.

[41] J. W. Kiragu, P. Mathengen, and E. Kireger, "Growth performance of Moringa oleifera planting materials derived from cuttings and seeds," International Journal of Plant Sciences, vol. 1, no. 4, pp. 142-148, 2015.

[42] F. L. Partelli, A. M. Covre, M. G. Oliveira, R. S. Alexandre, E. L. D. Vitória, and M. B. D. Silva, "Root system distribution and yield of 'Conilon' coffee propagated by seeds or cuttings," Pesquisa Agropecuária Brasileira, vol. 49, no. 5, pp. 349-355, 2014.

[43] D. Naidu and N. Jones, "The journey to successful commercial propagation and deployment of Eucalyptus dunnii cuttings," in Proceedings of the IUFRO Eucalypt Conference 2015, Zhanjiang, Guangdong, China, October 2015.

[44] B. B. Santoso and G. A. Parwata, "Seedling growth from stem cutting with different physiological ages of Jatropha curcas 
L. of west nusa tenggara genotypes," International Journal of Applied Science and Technology, vol. 4, no. 6, pp. 5-10, 2014.

[45] H. T. Hartmann, D. E. Kester, F. T. Davies Jr et al., Plant Propagation: Principles and Practices, Prentice Hall Inc, Hoboken, NJ, USA, 7th edition, 2002.

[46] R. R. B. Leakey, "Nauclea diderrichii: rooting of stem cuttings, clonal variation in shoot dominance, and branch plagiotropism," Trees, vol. 4, pp. 164-169, 1999.

[47] R. Henning, "The Jatropha booklet, A guide to the jatropha system and its dissemination in Zambia," 2003.

[48] J. Lynch, "Root architecture and plant productivity," Plant Physiology, vol. 109, no. 1, pp. 7-13, 1995.

[49] Z. Kraiem, W. Aidi Wannes, A. Zairi, and B. Ezzili, "Effect of cutting date and position on rooting ability and fatty acid composition of Carignan (Vitis vinifera L.) shoot," Scientia Horticulturae, vol. 125, no. 2, pp. 146-150, 2010. 